\title{
DIFFERENT DIETS WITH AND WITHOUT INCLUSION OF ANTIMICROBIAL ADDITIVES ALTER THE TOXICITY OF SWINE MANURE TO SPRINGTAILS AND EARTHWORMS?
}

\author{
DIFERENTES DIETAS COM E SEM INCLUSÃO DE ADITIVOS ANTIMICROBIANOS \\ ALTERAM A TOXICIDADE DO DEJETO DE SUÍNOS PARA COLEMBBOLOS E \\ MINHOCAS?
}
Suélen SERAFINI ${ }^{1}$; Kaine Cristine Cubas da SILVA ${ }^{1}$; Junior Gonçalves SOARES ${ }^{1}$; Ana Paula MACCARI ${ }^{\mathbf{~}}$;ulia Corá SEGAT ${ }^{\mathbf{1}}$; Aleksandro Schafer da SILVA ${ }^{\mathbf{1}}$; Diovani PAIANO ${ }^{1}$; Dilmar BARETTA ${ }^{1}$

1. Universidade do Estado de Santa Catarina (UDESC), Centro de Educação Superior do Oeste (UDESC Oeste), Chapecó, SC, Brazil. aleksandro.silva@udesc.br; dilmar.baretta@udesc.br.

\begin{abstract}
The objective of this study was to measure the impact on part of soil fauna of application of non-stabilized (fresh) manure from post-weaning pigs fed diets, formulated with or without the use of dual-purpose wheat ( $15 \%$ inclusion), and with or without the use of antimicrobial growth-promoting additives $\left(100 \mathrm{mg} \mathrm{kg}^{-1}\right.$ doxycycline $+50 \mathrm{mg} \mathrm{kg}^{-1}$ colistin $+250 \mathrm{mg} \mathrm{kg}^{-1} \mathrm{Zn}$ oxide). Two species of edaphic organisms were evaluated, the springtails Folsomia candida and the earthworms Eisenia andrei, using ecotoxicological avoidance behavior tests. The treatments were swine manure from: RR: Reference Ration; WR: Wheat Reference; RA: Reference Ration + Antimicrobial Additives; WA: Wheat Reference + Antimicrobial Additives. The doses of waste used for treatments were as follows: 0 (control), 5, 10, 20, 30, 40, 65 and $100 \mathrm{~m}^{3} \mathrm{ha}^{-1}$ for the springtails, and 0 (control), 5, 10, 20, 30, 40 and $65 \mathrm{~m}^{3} \mathrm{ha}^{-1}$ for the earthworms, applied in the Oxisol. The experimental design was completely randomized with four replicates. The use of non-stabilized swine manure did not affect the avoidance behavior of $F$. candida at any dose, regardless of the use of antimicrobial additives or wheat. For $E$. andrei, there was avoidance behavior at all treatments and doses used. These avoidance behaviors were related to the sensitivity of each species of soil organism. The avoidance behavior for earthworms was related to the doses of non-stabilized swine manure in soil and not to the various diets and/or the use of growth-promoting additives.
\end{abstract}

KEYWORDS: Eisenia andrei. Folsomia candida. Industrial swine farming. Swine waste. Terrestrial ecotoxicology.

\section{INTRODUCTION}

In industrial swine farming, the postweaning stage is marked by high incidence of gastrointestinal disorders (O'CONNELL; CALLAN; O'DOHERTY, 2006), caused by abrupt transition in diet from pre-weaning to post-weaning, with solid food intake (KIL; STEIN, 2010). In order to minimize this problem, antimicrobials in subtherapeutic dosages are added as growth promoters (OLIVER; WELLS, 2015) to reduce gastrointestinal disturbances that are peculiar to this stage, aiming to maintain animal health and improving swine feed conversion (SILVA, 2014).

Along with that, the economic/environmental pressures to reduce the cost of production and reduce the excretion of nutrients are major challenges in industrial swine farming (GILBERT et al., 2017). This has stimulated the use and study of food alternatives to corn and soybean in swine diets (FLOROUPANERI et al., 2014) by less common components such as dual-purpose wheat (WESENDONCK et al., 2013; QUATRIN et al., 2017).

In this context, the increased number of swine production annually results in an increase in the concentration of manure in small areas (OLIVEIRA et al., 2017). The use of swine manure as an agricultural fertilizer is a simple and economical alternative for discarding and recycling this material, in addition to the positive effects related to the increase of organic matter and soil fertility when properly used (CONGREVES et al., 2016; OLIVEIRA et al., 2017). The use of this material result on reduces the use of chemical fertilizers and contributes to the reduction of production costs.

It is common for this waste to be applied in the soil surface or to be incorporated in the soil. However, the use of this fertilizer without prior 
Different diets with and without inclusion...

analysis of its composition, or without adequate knowledge of the soil characteristics and the nutritional needs of the plants can result in excessive application or damage to the agricultural environment (OLIVEIRA et al., 2017). In addition, the presence of metabolites resulting from the degradation of the antimicrobial additives in the animal organism (GAVIOLI et al., 2013) can aggravate the problem and impact on non-target organisms responsible for organic matter degradation and nutrient cycling (ALVES et al., 2008; DOMENE et al., 2008; SEGAT et al., 2015; MACCARI et al., 2016).

The effects of swine manure on soil organisms require further study, although studies show that swine manure can cause edaphic toxicity and also that the presence of antibiotics in the soil is aggravating the loss of biological diversity, there are no studies that show how different dietary ingredients can affect the dynamics of this organic matrix, composed of waste and drug residues used as growth promoters, on the avoidance behavior of edaphic organisms. For this purpose, the avoidance behavior test can be used to provide quick and effective identification of pollutants and contaminants, as well as to make preliminary identification of the standard behavior of organisms in a determined soil after the application of some substance soil (SEGAT et al., 2015). Therefore, the objective of this study was to evaluate the effect of the application in soil of non-stabilized (fresh) swine manure derived from different diets, formulated with or without the use of dual-purpose wheat, and with or without inclusion of antimicrobial growth-promoting additives, by means of ecotoxicological avoidance behavior tests for two standard soil organisms, springtails and earthworms.

\section{MATERIAL AND METHODS}

\section{Soil collection and analysis}

In order to best represent the Western region of the State of Santa Catarina, Brazil, a Oxisol with clay-like texture, according to United States Department of Agriculture (USDA, 2014), was
SERAFINI et al.

collected from the superficial layer (0-0.20 m depth) of a forested area with no history of organic or chemical fertilization or of application of pesticides, in the municipality of Chapecó, Santa Catarina, Brazil, on the premises of the Empresa de Pesquisa Agropecuária e Extensão Rural de Santa Catarina EPAGRI [27 $05^{\prime} 274^{\prime \prime} \mathrm{S}$ and $052^{\circ} 38^{\prime} 085^{\prime \prime} \mathrm{W}$ ]. After collection, the soil was dried in an oven $\left(65^{\circ} \mathrm{C}\right)$, sifted in a sieve (2-mm mesh) for the removal of coarse organic particles and mineral, and was then subjected in two freezing and thawing cycles (48 $\mathrm{h}$ at $-20{ }^{\circ} \mathrm{C}$ and $48 \mathrm{~h}$ at $25{ }^{\circ} \mathrm{C}$ ). Prior to the ecotoxicological tests, soil $\mathrm{pH}$ was corrected to 6.0 \pm 0.5 with the addition of calcium carbonate $\left(\mathrm{CaCO}_{3}\right)$ (ISO 10390, 2005), and the moisture was adjusted to $65 \%$ of the maximum water retention capacity (WRC) (ISO 11465, 1993). The soil used contained $49 \%$ clay, $2.7 \%$ organic matter, $3.95 \mathrm{~g} \mathrm{~kg}^{1}$ of total nitrogen, $1.4,0.8,79.7$ and $5.4 \mathrm{mg} \mathrm{kg}^{-1}$ of $\mathrm{Cu}, \mathrm{Zn}, \mathrm{Fe}$ and $\mathrm{Mn}$, respectively, and $15.6 \mathrm{cmol}_{\mathrm{c}}$ $\mathrm{dm}^{-3}$ of cation exchange capacity (CEC). The physical and chemical variables of the soil were obtained according to Tedesco, Volkweiss and Bohnen (1995).

\section{Collection and characterization of swine manure}

The study was divided into three stages, soil collection and characterization, swine manure collection and characterization, and the ecotoxicological tests. For the waste collection, four experimental diets were elaborated and supplied to the animals (RR: Reference Ration; WR: Wheat Reference; RA: Reference Ration + Antimicrobial Additives; WA: Wheat Reference + Antimicrobial Additives) in a $2 \times 2$ factorial scheme (with and without inclusion of antimicrobial growthpromoting additives, and with or without the use of dual-purpose wheat variety BRS Tarumã, with $15 \%$ inclusion) (Table 1). The growth-promoting additives used were calculated to have the concentration of $100 \mathrm{mg} \mathrm{kg}^{-1}$ of doxycycline, $50 \mathrm{mg}$ $\mathrm{kg}^{-1}$ of colistin and $250 \mathrm{mg} \mathrm{kg}^{-1}$ of $\mathrm{Zn}$ oxide. These diets characterized the four different types of swine manure used in the ecotoxicological tests.

Table 1. Centesimal, chemical and energetic composition of experimental diets.

\begin{tabular}{lllll}
\hline Items\% & $\mathrm{RR}^{\# 1}$ & $\mathrm{WR}^{\# 2}$ & $\mathrm{RA}^{\# 3}$ & $\mathrm{WA}^{\# 4}$ \\
\hline Whey Powder & 5.000 & 5.000 & 5.000 & 5.000 \\
Spray Dried Blood Plasma & 2.000 & 2.000 & 2.000 & 2.000 \\
Double Purpose Wheat & - & 15.000 & - & 15.000 \\
Ground Corn & 60.764 & 49.791 & 60.764 & 49.791 \\
Soybean Meal & 23.124 & 18.873 & 23.124 & 18.873 \\
Sugar & 5.000 & 5.000 & 5.000 & 5.000 \\
Dicalcium Phosphate & 1.713 & 1.559 & 1.713 & 1.559
\end{tabular}




\begin{tabular}{|c|c|c|c|c|}
\hline Limestone & 0.516 & 0.595 & 0.516 & 0.595 \\
\hline Soy Oil & 0.200 & 0.320 & 0.200 & 0.320 \\
\hline Micronutrient Pre-Mixing & 0.500 & 0.500 & 0.500 & 0.500 \\
\hline Caolin & 0.108 & 0.108 & - & - \\
\hline Mycotoxin Adsorbent & 0.300 & 0.300 & 0.300 & 0.300 \\
\hline Zn Oxide & - & - & 0.025 & 0.025 \\
\hline Doxycycline & - & - & 0.020 & 0.020 \\
\hline Colistin & - & - & 0.063 & 0.063 \\
\hline Common Salt & 0.280 & 0.277 & 0.280 & 0.277 \\
\hline L-Lysine $\mathrm{HCl}$ & 0.234 & 0.338 & 0.234 & 0.338 \\
\hline DL-Methionine & 0.123 & 0.131 & 0.123 & 0.131 \\
\hline L-Threonine & 0.095 & 0.128 & 0.095 & 0.128 \\
\hline L-Tryptophan & 0.024 & 0.034 & 0.024 & 0.034 \\
\hline L-Valine & 0.019 & 0.046 & 0.019 & 0.046 \\
\hline Total & 100 & 100 & 100 & 100 \\
\hline
\end{tabular}

Castrated male pigs, in stage post-weaning, body weight between $8-25 \mathrm{~kg}$ (four per diet group), were housed in Pekas-type metabolic cages for seven days to adapt to experimental diets, followed by five days of total excreta collection. Fecal and urine collections were performed twice a day (10 $\mathrm{AM}$ and $5 \mathrm{PM}$ ). The four groups of waste (RR, WR, RA and WA) were collected separately, weighed, packed in plastic bags and cooled to $-20{ }^{\circ} \mathrm{C}$. At the end of the sampling period, the samples from each diet were collected, homogenized and weighed. The chemical characterization of the wastes (Table 2) was performed according to the protocol described by Tedesco, Volkweiss and Bohnen (1995). Evaluations of the presence and concentration of growth-promoting additives in swine manure (Table 2) were carried out using an extraction method adapted from Zhou et al. (2013) and Maccari et al. (2016).

Table 2. Composition of swine manure from the four different diets (RR: Reference Ration; WR: Wheat Reference; RA: Reference Ration + Antimicrobial Additives; WA: Wheat Reference + Antimicrobial Additives).

\begin{tabular}{lllll}
\hline Variables & RR & WR & RA & WA \\
\hline $\mathrm{pH}\left(\mathrm{H}_{2} \mathrm{O}\right)$ & 7.5 & 7.1 & 6.9 & 6.9 \\
Moisture (\%) & 49.48 & 54.33 & 51.77 & 56.63 \\
Total Carbon (\%) & 43.53 & 54.15 & 51.48 & 38.38 \\
Total Nitrogen (\%) & 2.58 & 3.25 & 3.07 & 2.65 \\
$\mathrm{C} / \mathrm{N}$ & $16.9: 1$ & $16.7: 1$ & $16.8: 1$ & $14.5: 1$ \\
$\mathrm{P}\left(\mathrm{g} \mathrm{kg}^{-1}\right)$ & 33.9 & 22.6 & 24.8 & 24.3 \\
$\mathrm{~K}\left(\mathrm{~g} \mathrm{~kg}^{-1}\right)$ & 31.2 & 21 & 25.2 & 24 \\
$\mathrm{Zn}\left(\mathrm{mg} \mathrm{kg}^{-1}\right)$ & 380 & 300 & 840 & 730 \\
$\mathrm{Cu}\left(\mathrm{mg} \mathrm{kg}^{-1}\right)$ & 720 & 510 & 600 & 440 \\
$\mathrm{Mn}\left(\mathrm{mg} \mathrm{kg}^{-1}\right)$ & 210 & 190 & 200 & 170 \\
$\mathrm{Fe}\left(\mathrm{mg} \mathrm{kg}^{-1}\right)$ & 4370 & 3420 & 3940 & 3070 \\
$\mathrm{Colistin} \mathrm{A}\left(\mu \mathrm{g} \mathrm{g}^{-1}\right)$ & $\mathrm{Nd}$ & 1.35 & 37.90 & 59.59 \\
Colistin B $\left(\mu \mathrm{g} \mathrm{g}^{-1}\right)$ & $\mathrm{Nd}$ & 1.39 & 96.54 & 141.43 \\
Doxycycline $\left(\mu \mathrm{g} \mathrm{g}^{-1}\right)$ & $\mathrm{Nd}$ & $\mathrm{Nd}$ & $\mathrm{Nd}$ & $\mathrm{Nd}$ \\
\hline
\end{tabular}

$\mathrm{Nd}=$ Not detected

It should be noted that the experimental conditions allowed for the collection of contamination-free wastewater from facilities cleaning or rainwater, generating more dry matter waste than from commercial farms. In order to further reduce the water content, the materials were 
Different diets with and without inclusion...

subjected to laboratory drying for five days at room temperature $\left(22^{\circ} \mathrm{C}\right)$. The waste was stored in plastic trays $(25 \times 40 \times 7 \mathrm{~cm})$, on standard $1.5 \mathrm{~cm}$ high pallets to allow homogeneous drying.

It is important to note that the swine waste did not undergo stabilization and/or composting. This procedure was performed to simulate a condition of mis-use, i.e., without prior recommended treatment. It should be noted that the recommendation is for a minimum of 120 days of hydraulic retention time (HRT) (FATMA, 2014). In order to minimize the possible effects of the water contents in the execution of the ecotoxicological tests, the moisture content was standardized among the wastes (RR, WR, RA and WA) with the addition of distilled water according to the group that maintained the highest moisture content (56\%) (Table 2).

\section{Treatments evaluated}

The treatments consisted of doses of swine manure from the four experimental diets (RR, WR, RA and WA): 0 (control), 5, 10, 20, 30, 40, 65 and $100 \mathrm{~m}^{3} \mathrm{ha}^{-1}$ for Folsomia candida, and 0 (control), 5, 10, 20, 30, 40 and $65 \mathrm{~m}^{3} \mathrm{ha}^{-1}$ for Eisenia andrei, applied in the Oxisol. The definition of doses was based on the Normative Instruction $\mathrm{n}^{\circ} 11$ (IN 11) for disposal or use of pig manure as organic fertilizer in soil of the State of Santa Catarina, that set the maximum application of $50 \mathrm{~m}^{3} \mathrm{ha}^{-1}$ per year (FATMA, 2009), as well as the results of previous ecotoxicological studies with swine manure (SEGAT et al., 2015; MACCARI et al., 2016). The experiments were conducted in a completely randomized experimental design with four replications.

\section{Ecotoxicological tests}

For the avoidance behavior ecotoxicological tests, we used springtails and earthworms from the laboratory cultures maintained according to standard protocols, F. candida (ISO 11267, 1999) and E. andrei (ISO 17512-1, 2007), respectively. These species were selected because they are internationally recognized as soil quality bioindicators by the International Organization for Standardization (ISO).

The ecotoxicological avoidance behavior tests were based on the protocol ISO 17512-2 (2011) for $F$. candida and ISO 17512-1 (2007) for $E$. andrei. The tests were conducted under controlled conditions, in the dark and at a temperature of $20^{\circ} \mathrm{C} \pm 2{ }^{\circ} \mathrm{C}$, for a total duration of $48 \mathrm{~h}$.

\section{SERAFINI et al.}

For the $F$. candida tests, each experimental unit consisted of a round plastic container with a capacity of $150 \mathrm{~mL}$, a height of $6 \mathrm{~cm}$ and a crosssectional area of $6.5 \mathrm{~cm}$ in diameter. The containers were divided in half, with one side receiving $30 \mathrm{~g}$ of untreated control soil and the other receiving $30 \mathrm{~g}$ of soil treated with various doses $(5,10,20,30,40,65$ and $100 \mathrm{~m}^{3} \mathrm{ha}^{-1}$ ) of each treatment (RR, WR, RA and WA). To each unit was then added 20 springtails, aged synchronized between 10-12 days (after egg hatching) (ISO 17512-2, 2011).

For the E. andrei tests, each experimental unit consisted of a rectangular plastic container with a capacity of $1 \mathrm{~L}$, a height of $6 \mathrm{~cm}$ and a crosssectional area of $12.5 \mathrm{~cm}$. The containers were also divided in half, with one side receiving $250 \mathrm{~g}$ of untreated control soil and the other receiving $250 \mathrm{~g}$ of soil treated with various doses $(5,10,20,30,40$ and $65 \mathrm{~m}^{3} \mathrm{ha}^{-1}$ ) of each treatment (RR, WR, RA and WA). Each unit received 10 adult clitellate earthworms with body mass between 300-600 mg (ISO 17512-1, 2007).

In addition to the treatment groups, we assembled "double controls" consisting of containers that received untreated soil (control) on both sides, in order to verify the reliability of the test results from the validation criteria described by the protocols ISO 17512-2 (2011) and ISO 17512-1 (2007).

To disassemble the tests after $48 \mathrm{~h}$, a partition was inserted vertically in the middle of each container, dividing it into two sections (control or untreated soil $\mathrm{x}$ soil treated). The contents of each section were transferred to a new container and the organisms were counted (ISO 17512-1, 2007; ISO 17512-2, 2011).

\section{Statistical analysis}

The responses to the avoidance behavior tests were calculated according to the determination of the protocols ISO 17512-2 (2011) and ISO 17512-1 (2007), according to the following formula: $\mathrm{A}=((\mathrm{C}-\mathrm{T}) / \mathrm{N}) \times 100$, where A represents to the percentage of avoidance, $\mathrm{C}$ is the number of organisms in the control soil, $\mathrm{T}$ is the number of organisms in soil treated, and $\mathrm{N}$ is the total number of organisms. The total values of organisms found in the untreated control soil and soil treated in each of the combinations were evaluated using the Fisher's test (ZAR, 1996), which compares data obtained to those of expected results, considering a significance of $95 \%(\mathrm{p} \leq 0.05)$. 


\section{RESULTS AND DISCUSSION}

\section{Avoidance behavior of springtails}

The avoidance behavior tests for both species of edaphic organisms comply with the validation criteria for double controls. For $F$. candida, there was no lethality from the combination of control soils, and the distribution of the organisms between the sections was $57.5 \%$ and $42.5 \%$, in all treatments. For E. andrei, no lethality occurred and the distribution of organisms between the sections was $45 \%$ and $55 \%$ in all treatments.
SERAFINI et al.

The application of the wastes at various doses $\left(5,10,20,30,40,65\right.$ and $\left.100 \mathrm{~m}^{3} \mathrm{ha}^{-1}\right)$ did not cause avoidance behavior for $F$. candida in Oxisol with the tested treatments (RR, WR, RA and WA) $(p>0.05)$, but rather we observed that the majority of the organisms remained in the soil treated with swine manure from the lowest dose of application (5 $\mathrm{m}^{3} \mathrm{ha}^{-1}$ ): $90 \%$ with RR (Figure 1. A), $93.75 \%$ with WR (Figure 1. B), 80\% with RA (Figure 1. C), and $86.25 \%$ with WA (Figure 1. D).

$\mathbf{A}$

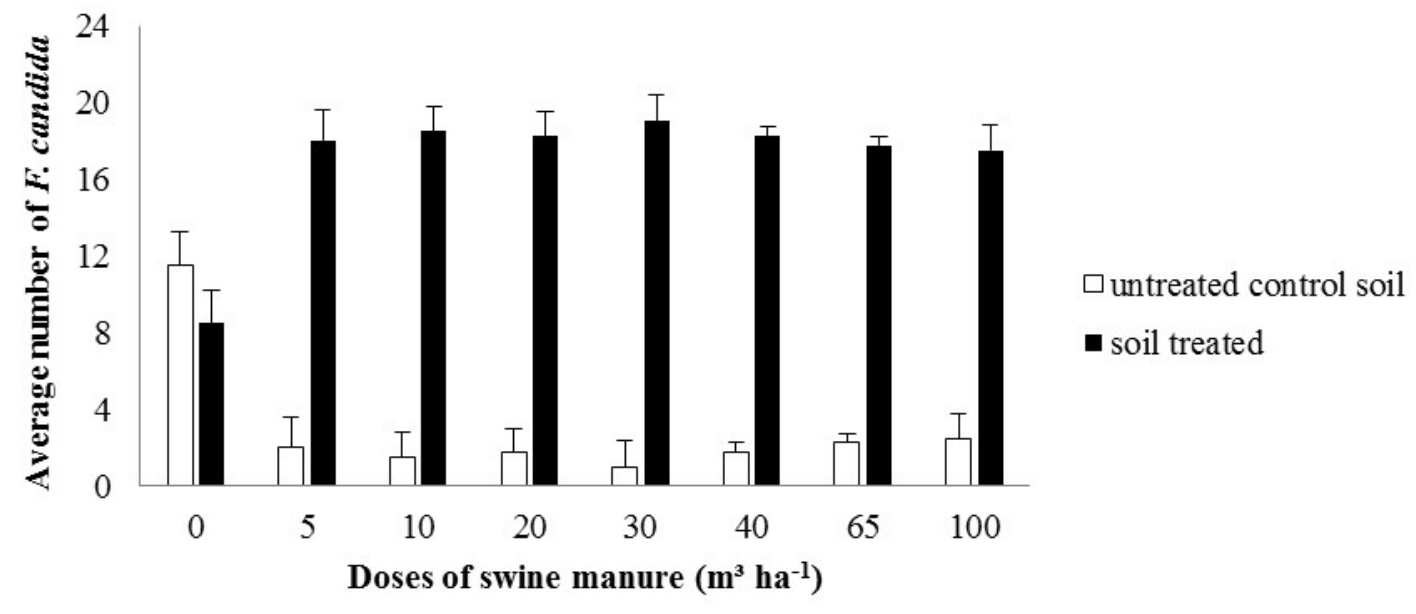

B

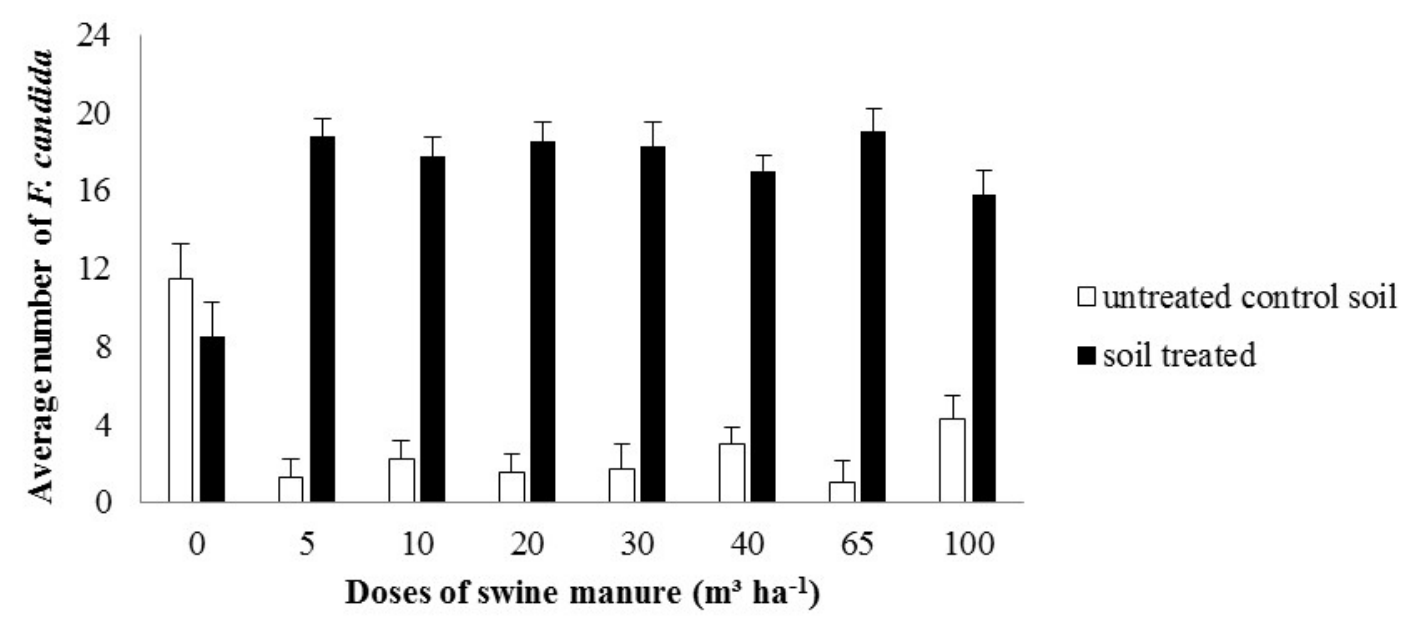




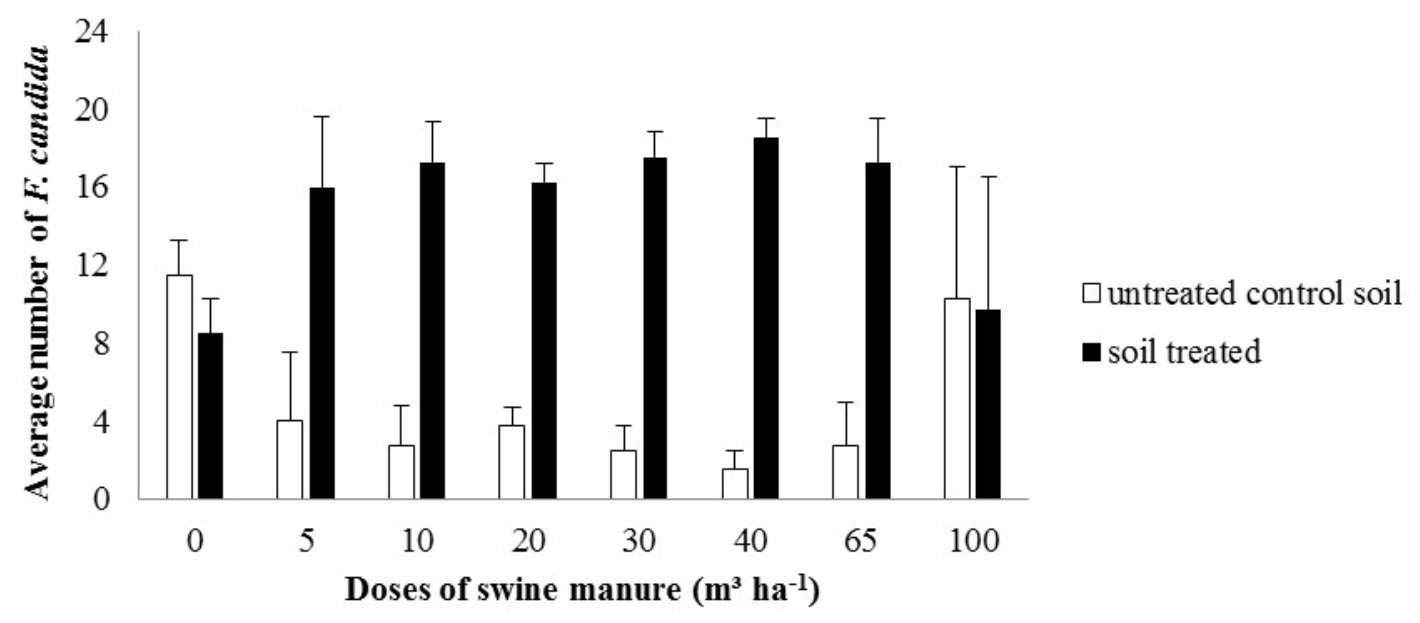

D

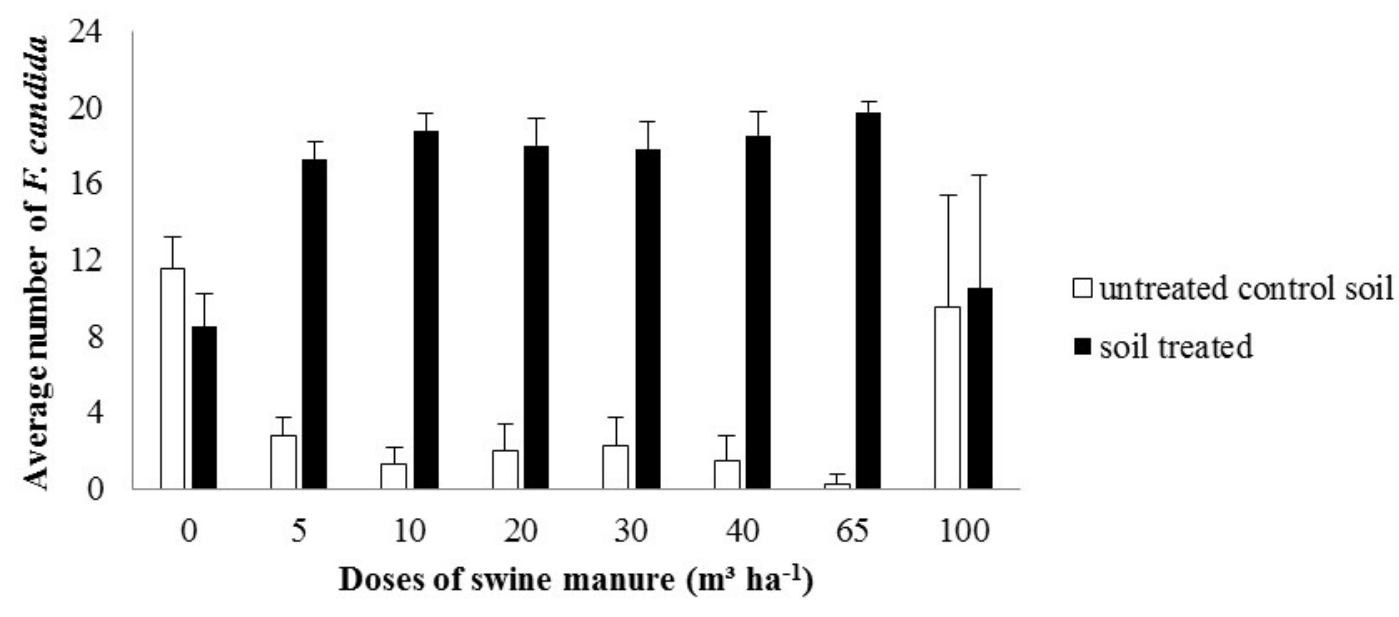

Figure 1. Average number of Folsomia candida in the avoidance behavior tests in Oxisol. Treatments: RR: Reference Ration [A]; WR: Wheat Reference (15\% wheat inclusion) [B]; RA: Reference Ration + Antimicrobial Additives (100 mg kg $\mathrm{mg}^{-1}$ doxycycline $+50 \mathrm{mg} \mathrm{kg}^{-1}$ colistin $+250 \mathrm{mg} \mathrm{kg}^{-1} \mathrm{Zn}$ oxide) [C]; WA: Wheat Reference (15\% wheat inclusion) + Antimicrobial Additives (100 mg kg-1 doxycycline + $50 \mathrm{mg} \mathrm{kg}^{-1}$ colistin $+250 \mathrm{mg} \mathrm{kg}^{-1} \mathrm{Zn}$ oxide) [D].

*Significant $\mathrm{p} \leq 0.05$ by Fisher's test. Standard deviation $(T)$. $(n=4)$.

This behavior occurs because springtails are abundant in diverse types of soils, which indicates that they can adapt to different environments, and they feed on organic matter (ZEPPELINI; BELLINI, 2004; ROSA; DALMOLIN, 2009; OLIVEIRA FILHO; BARETTA, 2016). In this way, swine manure when applied to the soil can be characterized as a source of food for edaphic fauna such as springtails (SEGAT et al., 2015; CONGREVES et al., 2016; OLIVEIRA et al., 2017).

Matos-Moreira et al. (2011) carried out some avoidance behavior tests with $F$. candida on non-fertilized soil that underwent two fertilization treatments: bovine leachate and chemical fertilizers, known as the "conventional fertilization strategy", and dairy industry waste was added to the conventional fertilization strategy; the springtails did not avoid fertilized soils in any of the combinations tested. The authors attributed this nonavoidance behavior to soil properties, including texture, and to organic matter with its low content of heavy metals.

Regarding the soil, the toxicity of swine manure may be less pronounced in Oxisol, when compared to more sandy soils, because it is associated with its greater capacity to retain nutrients, related to higher values of $\mathrm{CEC}$ and organic matter, in addition to particle size and the clay texture, in relation with a sandy or silt loam 
Different diets with and without inclusion...

texture soils, characteristics that condition the lower availability of some toxic metals to organisms of the soil that are added through the application of swine manure (CESAR et al., 2012; WAALEWIJNKOOL et al., 2013; SEGAT et al., 2015; MACCARI et al., 2016).

According to Peijnenburg et al. (2012), springtails are more sensitive to the toxicity of compounds or contaminants when they are dissolved in soil solution, since the main route of contamination of these organisms, due to exoskeleton protection, is by water absorption routes present in specialized organs. In this way, we can infer that short exposures to swine manure may not lead to the avoidance behavior in these organisms, however, after long exposures there may be toxicity of manure with respect to other variables, including survival and reproduction (MACCARI et al., 2016).

In this context, Maccari et al. (2016) when applying increasing doses of swine manure derived from different diets in Oxisol (clay texture) and in Entisol (sandy texture) and exposure of $F$. candida for 14 and 28 days, got $\mathrm{LC}_{50}$ (lethal concentration for $50 \%$ of the organisms) for the various wastes ranging from 87.0->100 $\mathrm{m}^{3} \mathrm{ha}^{-1}$ (Oxisol), and 17.89$22.6 \mathrm{~m}^{3} \mathrm{ha}^{-1}$ (Entisol). The values of $\mathrm{EC}_{50}$ (effective concentration that reduces reproduction by $50 \%$ ) for the various wastes ranged from $83.1-90.05 \mathrm{~m}^{3} \mathrm{ha}^{-1}$ for Oxisol, and from 9.8-16.5 $\mathrm{m}^{3} \mathrm{ha}^{-1}$ of swine manure for Entisol. These values confirm that $F$. candida despite the non-avoidance behavior of these organisms, there are toxic effects on other variables for the same species.

Maccari et al. (2016) also found that the toxicity effects of swine manure observed with respect to survival and reproduction of $F$. candida in Oxisol might be a consequence of higher concentrations of the $\mathrm{Cu}$ and $\mathrm{Zn}$ in the material added, with the proportional increase of the application rates. In the present study, another observed avoidance behavior response was a substantial reduction in the proportion of the number of organisms that remained in the soil treated with the highest dose of swine manure (100 $\mathrm{m}^{3} \mathrm{ha}^{-1}$ ) in two diets, both with addition of antimicrobial additives: $48.75 \%$ for RA (Figure 1 . C), and $52.5 \%$ for WA (Figure 1. D), which may indicate springtails avoidance at doses higher than those tested at work. In these applications dose of pig waste from these treatments there was a higher proportional concentration of $\mathrm{Zn}$ and colistin $\mathrm{A}$ and $\mathrm{B}$, compared to the same dose in the other treatments (Table 2).
SERAFINI et al.

The highest concentration of $\mathrm{Zn}$ in the RA and WA treatments was derived from the use of $\mathrm{Zn}$ oxide in the diets as a growth promoter, which, unlike antimicrobials is used at dosages above the recommended doses to meet the nutritional requirements of the pigs. Specifically, for the weight used, recommendations for meeting the nutritional requirements proposed by Rostagno et al. (2011) are about $90 \mathrm{mg} \mathrm{kg}^{-1}$ of $\mathrm{Zn}$. After the metabolism of this element in the animal, its excretion occurs mainly via feces (PEKAS, 1966) and can be disseminated in the soil via organic fertilization (GIROTTO et al., 2010). In toxic concentrations, $\mathrm{Zn}$ can damage soil fauna, because its retention occurs mainly in soil organic matter particles (ASHWORTH; ALLOWAY, 2004). In this way, it may be in contact with edaphic fauna that are responsible for organic matter degradation on soil. The $\mathrm{Zn}$ can bioaccumulates in these organisms and affects organic functions, altering biochemical processes, organelles and cell membranes (DIAS-JUNIOR et al., 1998).

This reduction of organisms at dose of 100 $\mathrm{m}^{3} \mathrm{ha}^{-1}$ in the RA and WA treatments, with the addition of antimicrobial additives, besides being an indication that avoidance behavior may occur for pig waste concentrations greater than $100 \mathrm{~m}^{3} \mathrm{ha}^{-1}$, may also be an indication that the metabolism of these additives alone or in combination can generate metabolites that alter the toxicity of waste, since antibiotics are specifically developed to control bacteria in the animal body, making them potentially hazardous to bacteria and other microorganisms in the environment (WARMAN, 1980; PURSELL; SAMUELSEN; SMITH, 1995).

In another specific study with antibiotics, Baguer, Jensen and Krogh (2000) evaluated the effects of molecules of the same group as those used in this study, tylosin and oxytetracycline applied directly to soil in springtails Folsomia fimetaria, and found low toxicity for these organisms. These authors suggested the improbability that these molecules in animal excreta cause direct risk to the soil fauna. However, they also emphasized that, because soil ecosystems are built by complex and interconnected food webs, it is not yet possible to exclude the possibility of indirect effects on soil fauna, driven by changes in the decomposition system caused by changes in microbial communities.

Although few studies have evaluated the soil effects of the antimicrobials tested in this study, in studies that evaluated the toxicity of other veterinary substances in the soil, the authors reported that toxicity directly depended on the 
physical and chemical characteristics of each molecule or compound, its metabolites, solubility and bioavailability, and the mode and time of degradation that determine the persistence of these compounds in the ecosystem, as well as the acute or chronic action on edaphic organisms (BOXALL et al., 2003; ZORTÉA et al., 2017). They also pointed out that concentrations affecting soil fauna were higher than the levels usually detected in the environment (BOXALL et al., 2008; REGITANO; LEAL, 2010). However, the effects of secondary metabolites, produced during the metabolism of antibiotics in the animal organism, cannot be ruled out. These products may be more toxic than the original molecules (BOXALL et al., 2008) such as is the case of tetracycline, which may have metabolites toxics for soil organisms that is similar toxicity to or even greater than that of the molecule in its original form (HALLING-SØRENSEN; NIELSEN; JENSEN, 2002; MOJICA; AGA, 2011).

\section{Avoidance behavior of earthworms}

The E. andrei in Oxisol, we observed avoidance behavior at all doses of applied swine manure $\left(5,10,20,30,40\right.$ and $\left.65 \mathrm{~m}^{3} \mathrm{ha}^{-1}\right)$, independent of treatment (RR, WR, RA and WA) (p $\leq 0.05$ ) (Figure 2. A, B, C and D).

A

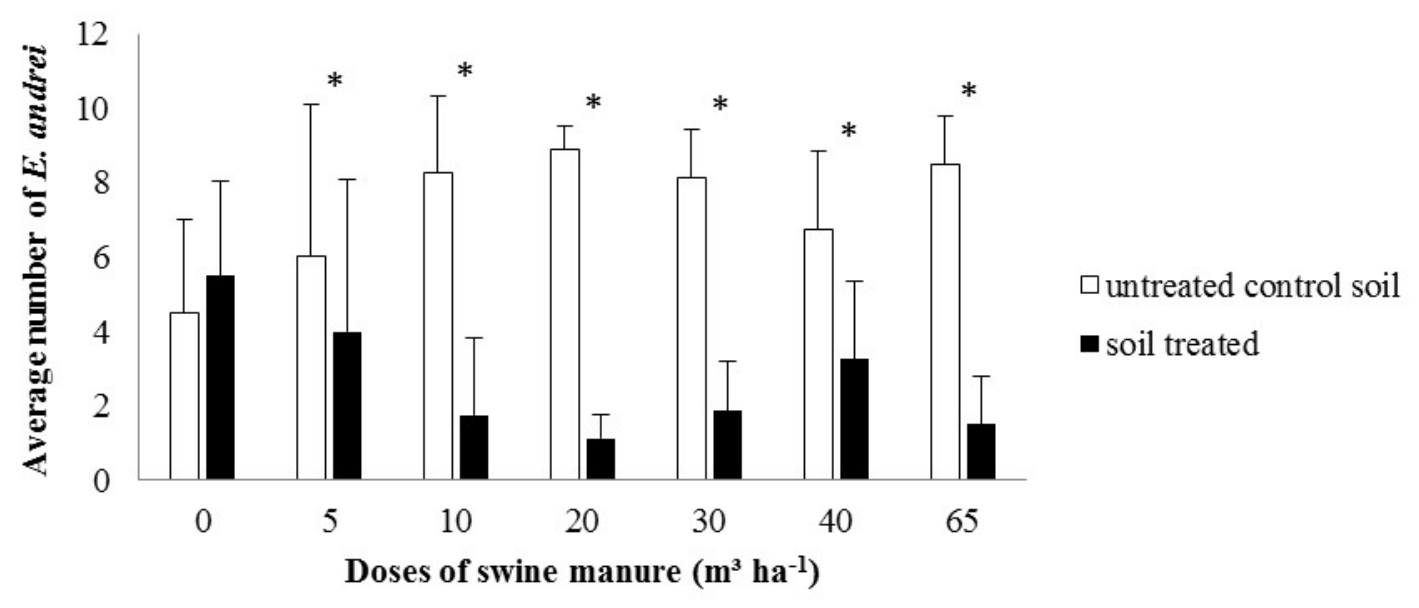

B

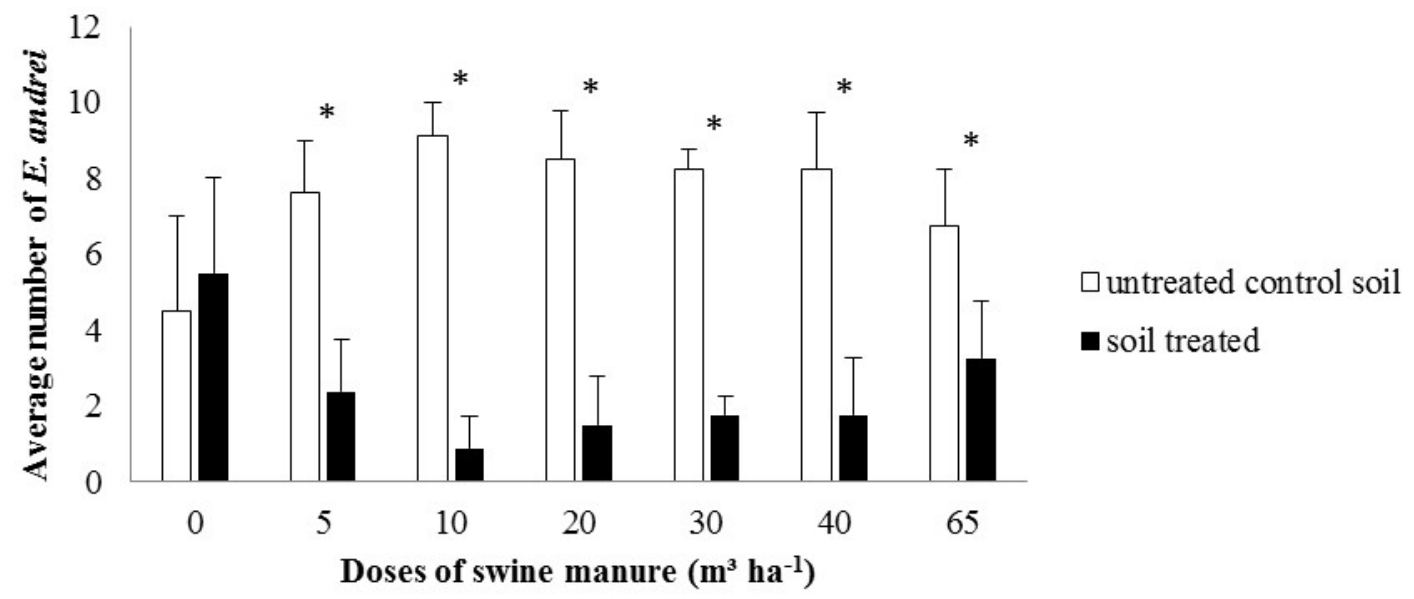




\section{C}

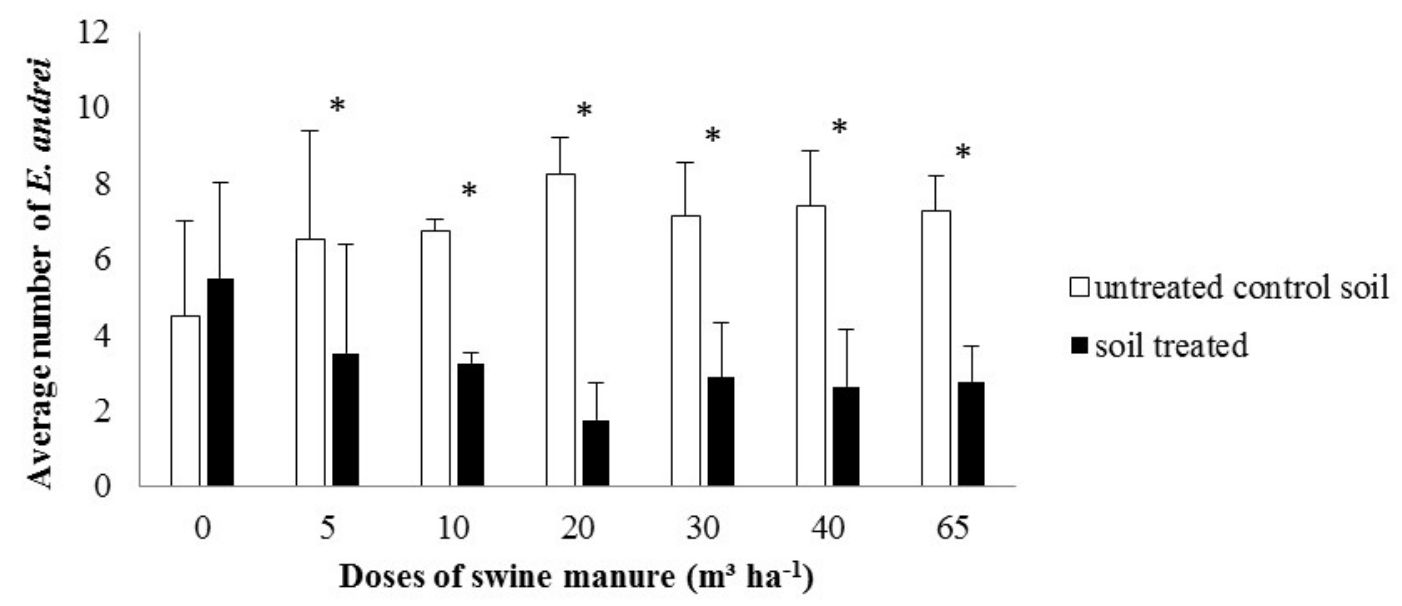

D

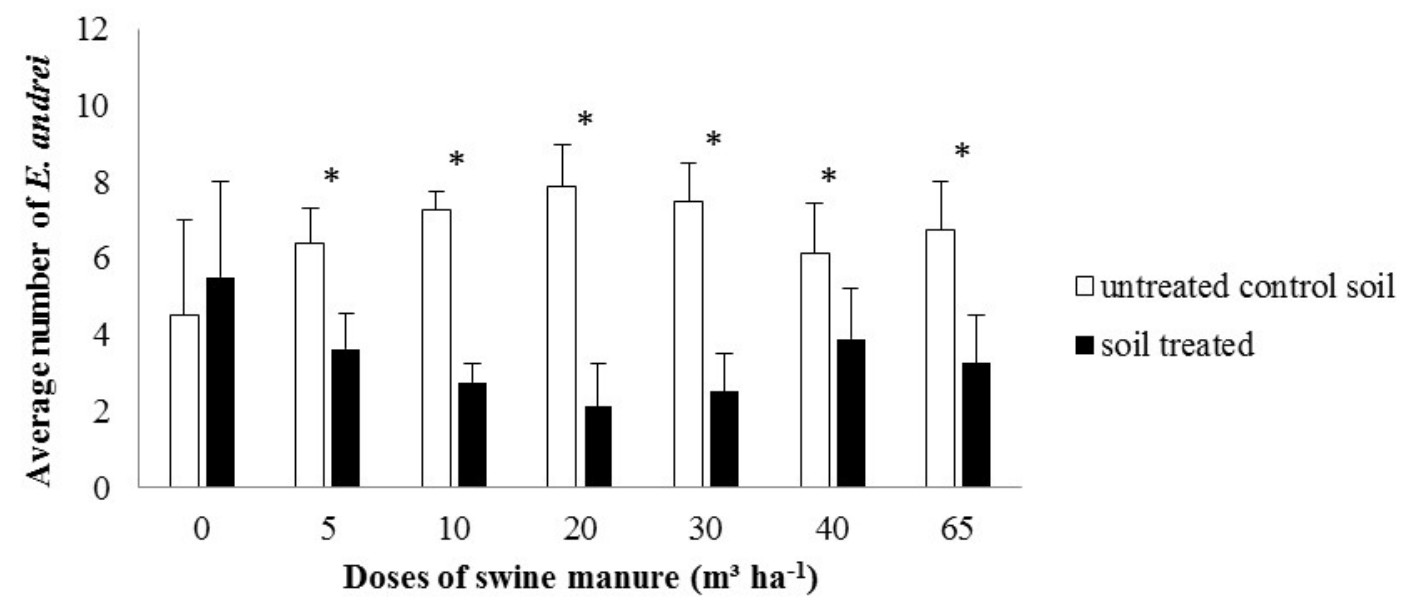

Figure 2. Average number of Eisenia andrei in the avoidance behavior tests in Oxisol. Treatments: RR: Reference Ration [A]; WR: Wheat Reference (15\% wheat inclusion) [B]; RA: Reference Ration + Antimicrobial Additives (100 mg kg ${ }^{-1}$ doxycycline $+50 \mathrm{mg} \mathrm{kg}^{-1}$ colistin $+250 \mathrm{mg} \mathrm{kg}^{-1} \mathrm{Zn}$ oxide) [C]; WA: Wheat Reference (15\% wheat inclusion) + Antimicrobial Additives $\left(100 \mathrm{mg} \mathrm{kg}^{-1}\right.$ doxycycline + $50 \mathrm{mg} \mathrm{kg}^{-1}$ colistin $+250 \mathrm{mg} \mathrm{kg}^{-1} \mathrm{Zn}$ oxide) [D]. *Significant $\mathrm{p} \leq 0.05$ by Fisher's test. Standard deviation $(T)$. $(n=4)$.

The magnitude of the effects was primarily due to the addition of swine manure in the soil, since the avoidance behavior was already observed from the lowest dose used $\left(5 \mathrm{~m}^{3} \mathrm{ha}^{-1}\right)$ in all treatments. The absence of differences in toxicity between swine manure with different compositions, in the presence (RA and WA) or absence (RR and WR) of antimicrobial growth-promoting additives is explained by the non-detection or the low concentration of these antibiotics in the swine manure (Table 2).

As the avoidance behavior was independent of the composition of the wastes, it was not influenced by the composition of the diets supplied to the pigs. The change in the diet composition with the inclusion of wheat, although performed as a strategy to reduce costs, also promotes improvements related to feeding, digestion and nutritional use of food by pigs during the postweaning period (SCHOLTEN et al., 2002; WESENDONCK et al., 2013). This practice is also justified by the reduction of the need for corn and soybean by the swine chain (ABCS, 2016).

In a study by Matos-Moreira et al. (2011), previously cited, E. andrei earthworms avoidance behavior tests were carried out on soils that received bovine leachate and chemical fertilizers (called conventional strategy), and dairy industry waste added to the conventional strategy. However, unlike springtails $F$. candida, the earthworms avoided soils 
Different diets with and without inclusion...

fertilized with waste. E. andrei are sensitive to the presence of various pollutants in the soil, and are the standard organisms most commonly used in ecotoxicological tests (SEGAT et al., 2015) because they are primarily exposed to contaminants through direct absorption through the skin, through contact with the soil solution and through ingestion of soil particles (ALVES et al., 2015). These aspects that may explain the higher sensitivity of these organisms when compared to $F$. candida, as the springtails are less exposed to soil solution (OLIVEIRA FILHO et al., 2017).

Natal-da-Luz, Römbke and Sousa (2008) showed that earthworms preferred soils with higher content of organic matter and coarse texture, regardless of the level of soil contamination. Segat et al. (2015) evaluated the application of various doses of swine manure $\left(0,25,50,75\right.$ and $100 \mathrm{~m}^{3}$ ha $^{-}$ $\left.{ }^{1}\right)$ on avoidance behavior of $E$. andrei in Oxisol, and they found that the earthworms avoided contaminated soil only from $100 \mathrm{~m}^{3} \mathrm{ha}^{-1}$. These results were different from those obtained in the present study, in which there was avoidance behavior at all tested doses of swine manure $(5,10$, 20, 30, 40 and $65 \mathrm{~m}^{3} \mathrm{ha}^{-1}$ ). This can be explained by difference in the dry matter levels of the wastes used in the studies.

The results observed can be associated with the increase in the concentration of micronutrients $(\mathrm{Cu}$ and $\mathrm{Zn})$. Metals are the primary pollutants of the soil and are a potential threat to animal and plant life, therefore generating great global concern (GHOSH, 2018). In addition, soil properties influence the bioavailability of contaminants, as well as the persistence and movement of these through the soil compartments (NIEMEYER; CHELINHO; SOUSA, 2017). $\mathrm{Cu}$ and $\mathrm{Zn}$, among other metals, can affect the immune system of $E$. andrei (MASSICOTTE et al., 2003), and as a consequence, the overall health of the organism (GHOSH, 2018).

Another factor that may be associated with the response was the incorporation of non-stabilized waste as recommended by the Normative Instruction $\mathrm{n}^{\circ} 11$ (IN 11), different from the works mentioned with swine manure, dairy industry waste and bovine manure, that following aspects of the legislation for the previous stabilization process and limits of use. In this way, our results confirm the need for a period of previous stabilization of the waste as recommended by IN 11 (FATMA, 2014).

Previous stabilization can mitigate the environmental risks posed by organic waste, by the use or disposal in the soil as organic fertilizer (VALENTE et al., 2016), because swine farming
SERAFINI et al.

can generate effluents with high environmental damage potential (STEINMETZ et al., 2009). Thus, this process is performed to reduce or inactivate pathogenic microorganisms and the toxicity of this residue before being applied in the soil. The use of non-stabilized sewage can inhibit seed germination and root elongation, in addition to contaminating the soil and the environment. Therefore, in order to reduce the risks involved in recycling swine manure, it is prudent to ensure a minimum HRT for carbon and water loss and for nitrogen to be mineralized, as well as for some nutrients to be partially solubilized (SEDIYAMA et al., 2008).

It is necessary to emphasize the need to establish a strategy related to the volume of application of swine manure as soil fertilizer, considering the chemical composition of the residue, the soil characteristics and support, the nutritional requirements of the crops and the results obtained in ecotoxicological tests (MACCARI et al., 2016). Although the use of swine manure as fertilizer in agriculture is a simple and economical alternative to disposal and recycling, in addition to having positive effects on soil organic matter (OLIVEIRA et al., 2017). Excessive application without previous stabilization may compromise soil invertebrate activity and may consequently affect water infiltration, fragmentation and decomposition of organic material, regulation of microbial activity and soil structure (CARDOSO et al., 2013), aspects conducive to negative environmental impacts (GILBERT et al., 2017).

In addition, soil is one of the primary compartments in environmental and human risk assessments, because it has the capacity to provide ecosystem services in terms of food production, serving as a "reservoir" of biodiversity and as a regulator of gases, water and nutrients. Therefore, in order to reduce environmental pressures, it is essential to understand the implications of a contaminant, to improve waste management and to protect environmental resources (OLIVEIRA FILHO et al., 2017).

The results obtained in this study demonstrate that the volume of swine manure alone was an inefficient measure for the correct use as agricultural fertilizer, because for a proper use, the composition of the wastes, and particularly the type of soil must be considered. Finally, according to Renaud et al. (2017), when combining chemical and ecotoxicological data, it is possible to postulate as to potential sources of toxicity, contributing to better waste management practices and safer organic soil correction products. 


\section{CONCLUSIONS}

The use of different diets with and without inclusion of antimicrobial additives did not alter the toxicity of swine manure to avoidance behavior of springtails and earthworms.

The use of non-stabilized swine manure did not affect the avoidance behavior of springtails $F$. candida at any dose, regardless of the use of antimicrobial additives or dual-purpose wheat.

For earthworms E. andrei, avoidance behavior was observed for all treatments and doses used. The avoidance behavior was related to the sensitivity of each species tested and, in this study, it was higher for earthworms and was related to doses of non-stabilized swine manure and not to the various diets and/or the use of growth-promoting additives in pig diets.

\section{ACKNOWLEDGMENTS}

The authors would like to thank the coordination and employees of the Escola Básica Municipal Agropecuária Demétrio Baldissarelli for the availability of facilities and animals, the VITAMIX - Nutrição Animal for the donation of nutritional supplements and the Conselho Nacional de Desenvolvimento Científico e Tecnológico (CNPq) for financial assistance. This work was supported by CNPq [562650/20105/REPENSA/CNPq].

RESUMO: O estudo foi realizado com objetivo de mensurar o impacto sobre parte da fauna do solo de aplicações de dejetos sem estabilização (frescos), provenientes de suínos na fase de creche arraçoados com diferentes dietas, formuladas com ou sem o uso do trigo de duplo propósito ( $15 \%$ de inclusão), e com ou sem o uso de aditivos antimicrobianos promotores de crescimento $\left(100 \mathrm{mg} \mathrm{kg}^{-1}\right.$ de doxiciclina $+50 \mathrm{mg} \mathrm{kg}^{-1} \mathrm{de}$ colistina $+250 \mathrm{mg} \mathrm{kg}^{-1}$ de óxido de $\mathrm{Zn}$ ). Foram avaliadas duas espécies de organismos edáficos, colêmbolos Folsomia candida e minhocas Eisenia andrei, com o uso de ensaios ecotoxicológicos de comportamento de fuga. Os tratamentos foram dejetos de suínos provenientes de: RR: Ração Referência; WR: Trigo Referência; RA: Ração Referência + Aditivos Antimicrobianos; WA: Trigo Referência + Aditivos Antimicrobianos. As doses de dejetos utilizadas para os tratamentos foram: 0 (controle), 5, 10, 20, 30, 40, 65 e $100 \mathrm{~m}^{3} \mathrm{ha}^{-1}$ para os colêmbolos, e 0 (controle), 5, 10, 20, 30, 40 e $65 \mathrm{~m}^{3} \mathrm{ha}^{-1}$ para as minhocas, aplicadas em Latossolo Vermelho distrófico. O delineamento experimental foi inteiramente casualizado com quatro réplicas. A utilização de dejetos de suínos não estabilizados não afetou a fuga de $F$. candida em nenhuma das doses, independente do uso ou não de aditivos antimicrobianos ou de trigo. Já para $E$. andrei o comportamento foi inverso e houve fuga em todos os tratamentos e doses utilizados. Os comportamentos de fuga foram relacionados à sensibilidade de cada espécie de organismo edáfico. O comportamento de fuga para minhocas foi relacionado com as doses dos dejetos de suínos não estabilizados no solo e não às várias dietas e/ou ao uso dos aditivos promotores de crescimento.

PALAVRAS-CHAVE: Ecotoxicologia terrestre. Eisenia andrei. Folsomia candida. Resíduo suíno. Suinocultura.

\section{REFERENCES}

ASSOCIAÇÃO BRASILEIRA DOS CRIADORES DE SUÍNOS - ABCS. Mapeamento da suinocultura

brasileira. 1. ed. Brasília, 2016, 374 p. http://www.abcs.org.br/attachments/01_Mapeamento_COMPLETO_bloq.pdf (accessed 08 March 2018).

ALVES, M. V.; SANTOS, J. C. P; GOIS, D. T.; ALBERTON, J. V.; BARETTA, D. Soil macrofauna as influenced by chemical fertilizers and swine manure use in western Santa Satarina state, Brazil. Revista Brasileira de Ciência do Solo, Viçosa, v. 32, n. 2, p. 589-598, Mar./Apr. 2008. http://dx.doi.org/10.1590/S0100-06832008000200014

ALVES, P. R.; NATAL-DA-LUZ, T.; SOUSA, J. P.; CARDOSO, E. J. Ecotoxicological characterization of sugarcane vinasses when applied to tropical soils. Science of the Total Environment, Amsterdam, v. 526, n. 1, p. 222-232, Sep. 2015. http://dx.doi.org/10.1016/j.scitotenv.2015.03.150 
ASHWORTH, D. J.; ALLOWAY, B. J. Soil mobility of sewage sludge-derived dissolved organic matter, copper, nickel and zinc. Environmental Pollution, Amsterdam, v. 127, n. 1, p. 137-144, Jan. 2004. http://doi.org/10.1016/S0269-7491(03)00237-9

BAGUER, A. J.; JENSEN, J.; KROGH, P. H. Effects of the antibiotics oxytetracycline and tylosin on soil fauna. Chemosphere, Amsterdam, v. 40, n. 7, p. 751-757, Apr. 2000. http://doi.org/10.1016/S00456535(99)00449-X

BOXALL, A. B. A.; KOLPIN, D. W.; HALLING-SØRENSEN, B.; TOLLS, J. Peer reviewed: are veterinary medicines causing environmental risks? Environmental Science and Technology, Washington, v. 37, n. 15, p. 286-294, Aug. 2003. http://doi.org/10.1021/es032519b

BOXALL, A. B. A.; KAY, P.; BLACKWELL, P. A.; FOGG, L. A. Fate of veterinary medicines applied to soils. In: KÜMMERER, K. (Eds.), Pharmaceuticals in the environment: sources, fate, effects and risks, Berlin, p. 165-180, 2008. http://doi.org/10.1007/978-3-662-09259-0_14

CARDOSO, E. J. B. N.; VASCONCELLOS, R. L. F.; BINI, D.; MIYAUCHI, M. Y. H.; SANTOS, C. A.; ALVES, P. R. L.; PAULA, A. M.; NAKATANI, A. S.; PEREIRA, J. M.; NOGUEIRA, M. A. Soil health: looking for suitable indicators. What should be considered to assess the effects of use and management on soil health? Scientia Agricola, Piracicaba, v. 70, n. 4, p. 274-289, Jul./Aug. 2013. http://dx.doi.org/10.1590/S010390162013000400009

CESAR, R.; SILVA, M.; COLONESE, J.; BIDONE, E.; EGLER, S.; CASTILHOS, Z.; POLIVANOV, H. Influence of the properties of tropical soils in the toxicity and bioavailability of heavy metals in sewage sludgeamended lands. Environmental Earth Sciences, [S.1.], v. 66, n. 8, p. 2281-2292, Aug. 2012.

http://dx.doi.org/10.1007/s12665-011-1449-2

CONGREVES, K. A.; GRANT, B. B.; DUTTA, B.; SMITH, W. N.; CHANTIGNY, M. H.; ROCHETTE, P.; DESJARDINS, R. L. Predicting ammonia volatilization after field application of swine slurry: DNDC model development. Agriculture, Ecosystems and Environment, [S.1.], v. 219, p. 179-189, Mar. 2016. http://doi.org/10.1016/j.agee.2015.10.028

DIAS-JUNIOR, H. E.; MOREIRA, F. M. S.; SIQUEIRA, J. O.; SILVA, R. Heavy metals, microbial density and activity in a soil contaminated by wastes from a zinc industry. Revista Brasileira de Ciência do Solo, Viçosa, v. 22, n. 4, p. 631-640, Oct./Dec. 1998. http://dx.doi.org/10.1590/S0100-06831998000400008

DOMENE, X.; RAMÍREZ, W.; MATTANA, S.; ALCAÑIZ, J. M.; ANDRÉS, P. Ecological risk assessment of organic waste amendments using the species sensitivity distribution from a soil organisms test battery.

Environmental Pollution, Amsterdam, v. 155, n. 2, p. 227-236, Sep. 2008.

http://dx.doi.org/10.1016/j.envpol.2007.12.001

FUNDAÇÃO DO MEIO AMBIENTE - FATMA. Instrução Normativa nº 11 (IN 11), 2009. Suinocultura. Fundação do Meio Ambiente de Santa Catarina.

http://www.fatma.sc.gov.br/ckfinder/userfiles/arquivos/ins/11/IN\%2011\%20Suinocultura.pdf (accessed 08 March 2018).

FUNDAÇÃO DO MEIO AMBIENTE - FATMA. Instrução Normativa nº 11 (IN 11), 2014. Suinocultura. Fundação do Meio Ambiente de Santa Catarina.

http://www.fatma.sc.gov.br/ckfinder/userfiles/arquivos/ins/11/IN\%2011\%20Suinocultura.pdf (accessed 08 March 2018). 
FLOROU-PANERI, P.; CHRISTAKI, E.; GIANNENAS, I.; BONOS, E.; SKOUFOS, I.; TSINAS, A.; TZORA, A.; PENG, J. Alternative protein sources to soybean meal in pig diets. Journal of Food, Agriculture and Environment, Helsinki, v. 12, n. 2, p. 655-660, Jan. 2014.

http://www.researchgate.net/publication/272479939_Alternative_protein_sources_to_soybean_meal_in_pig_di ets

GAVIOLI, D. F.; OLIVEIRA, E. R.; SILVA, A. A.; ROMERO, N. C.; LOZANO, A. P.; SILVA, R. A. M.; BRIDI, A. M.; OBA, A.; SILVA, C. A. Effect of growth promoters for pigs on live performance, quality intestinal and the efficiency of biodigestion of wastes. Semina: Ciências Agrárias, Londrina, v. 34, n. 6, p. 3983-3998, Out. 2013. http://dx.doi.org/10.5433/1679-0359.2013v34n6Supl2p3983

GILBERT, H.; BILLON, Y.; BROSSARD, L.; FAURE, J.; GATELLIER, P.; GONDRET, F.; LABUSSIÈRE, E.; LEBRET, B.; LEFAUCHEUR, L.; LE FLOCH, N.; LOUVEAU, I.; MERLOT, E.; MEUNIER-SALAÜN, M. C.; MONTAGNE, L.; MORMEDE, P.; RENAUDEAU, D.; RIQUET, J.; ROGEL-GAILLARD, C.; VAN MILGEN, J.; VINCENT, A.; NOBLET, J. Review: divergent selection for residual feed intake in the growing pig. Animal, Cambridge, v. 11, n. 9, p. 1427-1439, Sep. 2017. http://dx.doi.org/10.1017/S175173111600286X

GIROTTO, E.; CERETTA, C. A.; BRUNETTO, G.; SANTOS, D. R.; SILVA, L. S.; LOURENZI, C. R.; LORENSINI, F.; VIEIRA, R. C. B.; SCHMATZ, R. Copper and zinc forms and accumulation in soil after successive pig slurry applications. Revista Brasileira de Ciência do Solo, Viçosa, v. 34, n. 3, p. 955-965, May./Jun. 2010. http://dx.doi.org/10.1590/S0100-06832010000300037

GHOSH, S. Environmental pollutants, pathogens and immune system in earthworms. Environmental Science and Pollution Research, [S.1.], v. 25, n. 7, p. 6196-6208, Mar. 2018. http://doi.org/10.1007/s11356-017-11678

HALLING-SØRENSEN, B.; NIELSEN S. N.; JENSEN, J. Environmental assessment of veterinary medicinal products in Denmark. Environmental Project $n{ }^{\circ}$ 659, 2002, Miljøprojekt. Danish Environmental Protection Agency, 2002. http://www2.mst.dk/udgiv/publications/2002/87-7944-971-9/pdf/87-7944-972-7.pdf (accessed 08 March 2018).

INTERNATIONAL ORGANIZATION OF STANDARDIZATION - ISO. ISO 11465, 1993. Soil quality Determination of dry matter and water content on a mass basis - Gravimetric method. Genève, Switzerland, 1993.

INTERNATIONAL ORGANIZATION FOR STANDARDIZATION - ISO. ISO 11267, 1999. Soil quality Inhibition of reproduction of Collembola (Folsomia candida) by soil pollutants. Genève, Switzerland, 1999 .

INTERNATIONAL ORGANIZATION FOR STANDARDIZATION - ISO. ISO 10390, 2005. Soil quality Determination of pH. Beuth-Verlag, Berlin, 2005.

INTERNATIONAL ORGANIZATION FOR STANDARDIZATION - ISO. ISO 17512-1, 2007. Soil quality Avoidance test for testing the quality of soils and effects of chemicals on behavior. Part 1: test with earthworms (Eisenia fetida and Eisenia andrei). Genève, Switzerland, 2007.

INTERNATIONAL ORGANIZATION FOR STANDARDIZATION - ISO. ISO 17512-2, 2011. Soil quality Avoidance test for determining the quality of soils and effects of chemicals on behavior. Part 2: test with collembolans (Folsomia candida). Genève, Switzerland, 2008.

KIL, D. Y.; STEIN, H. H. Invited Review: management and feeding strategies to ameliorate the impact of removing antibiotic growth promoters from diets fed to weanling pigs. Canadian Journal of Animal Science, Ottawa, v. 90, n. 4, p. 447-460, Jul. 2010. http://dx.doi.org/10.4141/CJAS10028 
MACCARI, A. P.; BARETTA, D.; PAIANO, D.; LESTON, S.; FREITAS, A.; RAMOS, F.; SOUSA, J. P.; KLAUBERG-FILHO, O. Ecotoxicological effects of pig manure on Folsomia candida in subtropical Brazilian soils. Journal of Hazardous Materials, Amsterdam, v. 314, p. 113-120, Aug. 2016.

http://doi.org/10.1016/j.jhazmat.2016.04.013

MASSICOTTE, R.; ROBIDOUX, P. Y.; SAUVÉ, S.; FLIPO, D.; FOURNIER, M.; TROTTIER, B. Immune response of earthworms (Lumbricus terrestris, Eisenia andrei and Aporrectodea tuberculata) following in situ soil exposure to atmospheric deposition from a cement factory. Journal of Environment Monitoring, [S.1.], v. 5, n. 5, p. 774-779, Oct. 2003. http://doi.org/10.1039/b301956j

MATOS-MOREIRA, M.; NIEMEYER, J. C.; SOUSA, J. P.; CUNHA, M.; CARRAL, E. Behavioral avoidance tests to evaluate effects of cattle slurry and dairy sludge application to soil. Revista Brasileira de Ciência do Solo, Viçosa, v. 35, n. 4, p. 1471-1477, Jul./Aug. 2011. http://dx.doi.org/10.1590/S0100-06832011000400041

MOJICA, E-RE.; AGA, D. S. 2011. Antibiotics pollution in soil and water: potential ecological and human health issues. In: NRIAGU, J. O. (Eds.), Encyclopedia of environmental health, Amsterdam, p. 97-110, 2011. http://doi.org/10.1016/B978-0-444-52272-6.00338-X

NATAL-DA-LUZ, T.; RÖMBKE, J.; SOUSA, J. P. Avoidance tests in site-specific risk assessment-influence of soil properties on the avoidance response of Collembola and earthworms. Environmental Toxicology and Chemistry, Michigan, v. 27, n. 5, p. 1112-1117, May. 2008. http://doi.org/10.1897/07-386.1

NIEMEYER, J. C.; CHELINHO, S.; SOUSA, J. P. Soil ecotoxicology in Latin America: current research and perspectives. Environmental Toxicology and Chemistry, Michigan, v. 36, n. 7, p. 1795-1810, Jul. 2017.

http://doi.org/10.1002/etc.3792

O'CONNELL, J. M.; CALLAN, J. J.; O'DOHERTY, J. V. The effect of dietary crude protein level, cereal type and exogenous enzyme supplementation on nutrient digestibility, nitrogen excretion, faecal volatile fatty acid concentration and ammonia emissions from pigs. Animal Feed Science Technology, Amsterdam, v. 127, n. 12, p. 73-88, Mar. 2006. http://doi.org/10.1016/j.anifeedsci.2005.09.002

OLIVEIRA FILHO, L. C. I.; BARETTA, D. Why should we care about edaphic springtails? Scientia Agraria, Curitiba, v. 17, p. 21-40, Dec. 2016.

http://www.researchgate.net/publication/311767661_Por_que_devemos_nos_importar_com_os_colembolos_ed aficos_Why_should_we_care_about_edaphic_springtails https://doi.org/10.5380/rsa.v $\overline{17 i} 2 . \overline{48} 2 \overline{42}$

OLIVEIRA FILHO, L. C. I.; BARETTA, D.; ZORTÉA, T.; OLIVEIRA, J. P. M.; SANTOS, J. C. P. Pyritic waste causes chronic and acute toxicity in Collembola and Oligochaeta. Scientia Agraria, Curitiba, v. 18, p. 64-75, Jan./Mar. 2017. http://doi.org/10.5380/rsa.v17i3.50209

OLIVEIRA, D. M. S.; LIMA, R. P.; BARRETO, M. S. C.; VERBURG, E. E. J.; MAYRINK, G. C. V. Soil organic matter and nutrient accumulation in areas under intensive management and swine manure application. Journal of Soil and Sediments, [S.1.], v. 17, n. 1, p. 1-10, Jan. 2017. http://doi.org/10.1007/s11368-016-14746

OLIVER, W. T.; WELLS, J. E. Lysozyme as an alternative to growth promoting antibiotics in swine production. Journal of Animal Science and Biotechnology, [S.1.], v. 6, n. 1, p. 35, Aug. 2015. http://doi.org/10.1186/s40104-015-0034-z

PAIANO, D.; NANTES, C. L.; KRAHL, G.; TUBIN, J. S. B.; CONTE, R. A.; DAL PIVO, J. C.; FERRAZ, S. M.; BARETTA, D. Digestibility of wheat grain dual purpose, BRS Tarumã cultivar, produced in agroecological or conventional system for pigs. Semina: Ciências Agrárias, Londrina, v. 35, n. 4, p. 2767 2778, Nov. 2014. http://dx.doi.org/10.5433/1679-0359.2014v35n4Suplp2767 
PEIJNENBURG, W.; CAPRI, E.; KULA, C.; LIESS, M.; LUTTIK, R.; MONTFORTS, M.; NIENSTEDT, K.; RÖMBKE, J.; SOUSA, J. P.; JENSEN, J. Evaluation of exposure metrics for effect assessment of soil invertebrates. Critical Reviews in Environmental Science and Technology, London, v. 42, n. 17, p. 18621893, Oct. 2012. http://doi.org/10.1080/10643389.2011.574100

PEKAS, J. C. Zinc 65 metabolism: gastrointestinal secretion by the pig. American Journal of Physiology, Bethesda, v. 211, n. 2, p. 407-413, Aug. 1966. http://doi.org/10.1152/ajplegacy.1966.211.2.407

PURSELL, L.; SAMUELSEN, O. B.; SMITH, B. Reduction in the in vitro activity of flumequine against Aeromonas salmonicida in the presence of the concentrations of $\mathrm{Mg}^{2+}$ and $\mathrm{Ca}^{2+}$ ions found in sea water. Aquaculture, Amsterdam, v. 135, n. 4, p. 245-255, Oct. 1995. http://doi.org/10.1016/0044-8486(95)01028-9

QUATRIN, M. P.; OLIVO, C. J.; MEINERZ, G. R.; FONTANELI, R. S.; AGUIRRE, P. F.; SEIBT, D. C.; AIRES, J. F.; FALK, D. R.; SAUTER, C. P.; SILVA, A. R. Productivity of dual-purpose wheat genotypes under grazing with lactating cows. Arquivo Brasileiro de Medicina Veterinária e Zootecnia, Belo Horizonte, v. 69, n. 6, p. 1615-1623, Nov./Dec. 2017. http://dx.doi.org/10.1590/1678-4162-9470

REGITANO, J. B.; LEAL, R. M. P. Performance and environmental impact of antibiotics in animal production in Brazil. Revista Brasileira de Ciência do Solo, Viçosa, v. 34, n. 3, p. 601-616, May./Jun. 2010. http://dx.doi.org/10.1590/S0100-06832010000300002

RENAUD, M.; CHELINHO, S.; ALVARENGA, P.; MOURINHA, C.; PALMA, P.; SOUSA, J. P.; NATALDA-LUZ, T. Organic wastes as soil amendments - Effects assessment towards soil invertebrates. Journal of Hazardous Materials, Amsterdam, v. 330, p. 149-156, May. 2017.

http://doi.org/10.1016/j.jhazmat.2017.01.052

ROSA, A. S.; DALMOLIN, R. S. D. Edafic fauna in constructed soil, native pasture and annual handling farm. Ciência Rural, Santa Maria, v. 39, n. 3, p. 913-917, May./Jun. 2009. http://dx.doi.org/10.1590/S010384782009000300044

ROSTAGNO, H. S.; ALBINO, L. F. T.; DONZELE, J. L.; GOMES, P. C.; OLIVEIRA, R. F.; LOPES, D. C.; FERREIRA, A. S.; BARRETO, S. L. T. Tabelas brasileiras para aves e suínos: composição de alimentos e exigências nutricionais. 3. ed. Viçosa, Universidade Federal de Viçosa, 2011, 252 p.

SCHOLTEN, R. H.; VAN DER PEET-SCHWERING, C. M.; DEN HARTOG, L. A.; BALK, M.; SCHRAMA, J. W.; VERSTEGEN, M. W. Fermented wheat in liquid diets: effects on gastrointestinal characteristics in weanling piglets. Journal of Animal Science, Champaign, v. 80, n. 5, p. 1179-1186, May. 2002.

http://doi.org/10.2527/2002.8051179x

SEDIYAMA, M. A. N.; VIDIGAL, S. M.; PEDROSA, M. W.; PINTO, C. L. O.; SALGADO, L. T. Fermentation of pig manure for use as an organic fertilizer. Revista Brasileira de Engenharia Agrícola e Ambiental, Campina Grande, v. 12, n. 6, p. 638-644, Nov./Dec. 2008. https://doi.org/10.1590/S141543662008000600011

SEGAT, J. C.; ALVES, P. R.; BARETTA, D.; CARDOSO, E. J. Ecotoxicological evaluation of swine manure disposal on tropical soils in Brazil. Ecotoxicology and Environmental Safety, Amsterdam, v. 122, p. 91-97, Dec. 2015. http://dx.doi.org/10.1016/j.ecoenv.2015.07.017

SILVA, C. A. Aditivos promotores de crescimento e repartidores de nutrientes na nutrição de suínos. In: ASSOCIAÇÃO BRASILEIRA DOS CRIADORES DE SUÍNOS (Eds.), Produção de suínos: teoria e prática. 1. ed. Brasília, 2014, $908 \mathrm{p}$.

STEINMETZ, R. L. R.; KUNZ, A.; DRESSLER, V. L.; FLORES, E. M. M.; MARTINS, A. F. Study of metal distribution in raw and screened swine manure. Clean: Soil, Air, Water, Weinheim, v. 37, n. 3, p. 239-244, Mar. 2009. http://doi.org/10.1002/clen.200800156 
TEDESCO, M. J.; VOLKWEISS, S. J.; BOHNEN, H. Análises de solo, plantas e outros materiais. 2. ed. Porto Alegre, Universidade Federal do Rio Grande do Sul, 1995, 174 p.

UNITED STATES DEPARTMENT OF AGRICULTURE - USDA. Soil survey staff: keys to soil taxonomy. 12. ed. USDA - Natural Resources Conservation Service, Washington, 2014.

VALENTE, B. S.; XAVIER, E. G.; LOPES, M.; PEREIRA, H. S.; ROLL, V. F. Composting and vermicomposting of dairy cattle residues and poultry bed. Archivos de Zootecnia, Córdoba, v. 65, n. 249, p. 79-87, Mar. 2016. https://doi.org/10.21071/az.v65i249.445

WAALEWIJN-KOOL, P. L.; ORTIZ, M. D.; LOFTS, S.; VAN GESTEL, C. A. The effect of pH on the toxicity of zinc oxide nanoparticles to Folsomia candida in amended field soil. Environmental Toxicology and Chemistry, Michigan, v. 32, n. 10, p. 2349-2355, Oct. 2013. http://doi.org/10.1002/etc.2302

WARMAN, P. R. The effect of amprolium and aureomycin [antibiotic] on the nitrification of poultry manureamended soil. Soil Science Society of America Journal, Madison, v. 44, n. 6, p. 1333-1334, Nov. 1980. http://doi.org/10.2136/sssaj1980.03615995004400060044x

WESENDONCK, W. R.; KESSLER, A. M.; RIBEIRO, A. M. L.; SOMENSI, M. L.; BOCKOR, L.; DADALT, J. C.; MONTEIRO, A. N. T. R.; MARX, F. R. Nutritional value and metabolizable energy of wheat by-products used for feeding growing pigs. Pesquisa Agropecuária Brasileira, Brasília, v. 48, n. 2, p. $203-$ 210, Feb. 2013. http://dx.doi.org/10.1590/S0100-204X2013000200011

ZAR, J. Biostatistical analysis. 3. ed. Prentice-Hall, London, 1996, 663 p.

ZEPPELINI, D. F.; BELLINI, B. C. Introdução ao estudo dos Collembola. João Pessoa, Universidade Federal da Paraíba, 2004, 82 p.

ZHOU, L. J.; YING, G. G.; LIU, S.; ZHANG, R. Q.; LAI, H. J.; CHEN, Z. F.; PAN, C. G. Excretion masses and environmental occurrence of antibiotics in typical swine and dairy cattle farms in China. Science of the Total Environment, Amsterdam, v. 444, p. 183-195, Feb. 2013. http://doi.org/10.1016/j.scitotenv.2012.11.087

ZORTÉA, T.; SEGAT, J. C.; MACCARI, A. P.; SOUSA, J. P.; DA SILVA, A. S.; BARETTA, D. Toxicity of four veterinary pharmaceuticals on the survival and reproduction of Folsomia candida in tropical soils. Chemosphere, Amsterdam, v. 173, p. 460-465, Apr. 2017. http://doi.org/10.1016/j.chemosphere.2017.01.069 